\title{
パーソナルモビリティの車種が 歩行者のリスク認知に与える影響に関する研究
}

\author{
菱川 貴之 1 ・井料 美帆 $2 \cdot$ 長谷川 悠 3 \\ 1学生会員 名古屋大学大学院 環境学研究科都市環境学専攻 ( $\bar{T} 464-8601$ 愛知県名古屋市千種区不老町) \\ E-mail: hishikawa.takayuki@h.mbox.nagoya-u.ac.jp \\ 2 正会員 名古屋大学大学院准教授 環境学研究科都市環境学専攻 (同上) \\ E-mail: iryo@nagoya-u.jp \\ 3非会員 A. T. カーニー（テ 107-6032 東京都港区赤坂1-12-32） \\ E-mail: sss.hasegawayu@gmail.com
}

\begin{abstract}
セグウェイに代表されるパーソナルモビリティ（PMV）は，コンパクトで小回りが利き，環境性能に優 れた手軽な交通手段として着目されている。普及には，客観的な安全性の確保のみならず，社会環境とし て PMV が歩行者の周りを走行する状況に対する歩行者の主観的な社会的受容性を検証すべきである. 本 研究では社会的受容の構成要因の 1 つであるリスク認知に着目し, 歩行者と混在する PMV に対する, 車 種，歩行者属性に応じた歩行者のリスク認知特性を調べることを目的とする. 形状の異なる PMV に対す るリスクを尋祇るアンケート調査を実施した。 因子分析の結果, 座位タイプは立位タイプに比べて安全で 信頼があり, リスクが小さく認知されることが明らかになった。 歩行者の属性（PMV の認知度, 普段の 歩行頻度等）による違いも明らかになった。
\end{abstract}

Key Words : personal mobility vehicles, social acceptance, risk perception, pedestrian

\section{1. はじめに}

\section{(1) 研究の背景と目的}

次世代のモビリティとして期待されているパーソナル モビリティ (PMV) は一人乗りの小さな乗り物である. PMV 利用のメリットは, 自動車に比べて少ないエネル ギー消費量で済むことや，高齢者や身体障害者などの交 通弱者の短距離の移動を支援しや寸いことである．近年, 大きさや走行特性の異なる多数の機種が開発されており, その一部は車道あるいは歩道の走行が認められている.

本論文で着目するのは, PMV の中でも, 歩行者と混 在可能な速度帯で走行することが可能で，かつ歩道を走 行できる程度に小さな車両である.このような車両の多 くは，低速・高速域いずれでも安定して走行が可能であ り, 状況に応じて自由に速度選択を行うことができるた め, コンパクトで柔軟に利用できる車両としての利用二 一ズは高いと考えられる. しかし現状，日本で歩道走行 可能な車両は, 最高速度が時速 $6 \mathrm{~km} / \mathrm{h}$ 以下でなければな らないことが道路交通法にて定められており，PMVの 多くは歩道走行の要件を満たすことができない.また, 車道走行するための法的要件も満たすことができず，公
道走行を認められていないのが現状である.

法的な課題をクリアし, PMV が公道走行可能となる ためには，このような小型 PMV が社会に受け入れられ るという確信が得られることが必須である.この時の社 会的な受容性とは, 当該車両の利用者の利便性が認めら れるのみならず，既存の交通への負の影響を最小限にし， 道路利用者の安全・安心を確保することで導入が受け入 れられることと言える. その際, 客観的な衝突安全性を 担保することは当然として, 主観的にも道路利用者が安 全・安心を感じることが求められる. 歩行者が PMV と の混在を強いられたとき，その環境を受け入れられるか どうかは, PMV との混在を歩行者がじの程度のリスク として認知するかによると考えられる.

知識や経験のないものを見たり体験したりするとき， 人は得られる限られた情報の中から判断する. 中でも, 第一印象として受けた情報に人の判断は左右されやすい と考えられる. 新たな PMV に対しても, 外見を中心と した限られた情報, および自身の経験や知識に基づく情 報とを関連付けてリスクを認知するのではないかと想定 される. 現状開発・提案されている PMV は多様であり, 立ち乗り (立位) か座り乗り (座位) かといった形状, 
走行速度などの運動特性が車種ごとに大きく異なる．こ うした PMVの多様性と歩行者の経験や属性はリスク認 知に大きく影響を与えると考えられ，リスク認知特性も これらを踏まえて比較すべきである.

そこで本研究では，PMVの車種それぞれに対して， 歩行者の属性に応じた歩行者のリスク認知の特性を調心 ることを目的とする.

\section{(2) 既往研究の整理と本研究の位置づけ}

PMV の受容性に関する既往研究としては，まず運転 者の利用意向を問うものが挙げられる. セグウェイやウ イングレットの体験乗車後に乗りやすさや利用意向を問

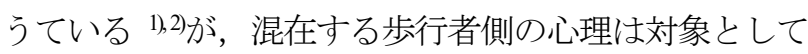
いない.また，それぞれ単独の車種を対象としており， 車種間の比較はできていない.

他の車両の混在に対して歩行者が認知するリスクにつ いては，自転車 3)との混在に関するもののほか，近年で は自動運転車両4)対象とした事例がある.PMVを対象 として歩行者の受容性を扱う研究は未だ限られているが, 衝突回避挙動に基づき客観的な安全性を評価するものと, PMV との交錯時の歩行者の心理をアンケート等で分析 するものがある.

このうち衝突回避挙動分析では, 中川ら 5゙は歩行者と PMV との回避行動を実験により評価し，歩行者が自転 車を回避するために確保するパーソナルスペースよりも， PMV に対して確保しようとするパーソナルスペースの 方が小さいこと, PMV の接近方向によってパーソナル スペースが異なることを明らかにしている．また Dias et al. ${ }^{0}$ はセグゥェイの歩行者回避挙動と歩行者のセグウェ イ回避挙動のモデルをそれぞれ実験データからキャリブ レーションし, 安全な回避に必要な距離・速度の関係を 考察している.

PMV の挙動が歩行者の心理に与える影響について, 中川らの一連の研究 7,8)では, 倒立振子型車両が歩行者 の心理に与える影響を分析しており，倒立振子型車両の ステップの高さ，歩行者密度，歩行者と車両との距離， 速度が影響因子として挙げられることを示した。さらに Hasegawa etal. ${ }^{9}$ ( は歩行者挙動モデルである Social Forceモデ ルを援用して，歩行者の主観的危険度を歩行者と車両の 相対位置・相対速度から定量化する手法を提案した。

しかしこれら PMV の受容性に関する研究は，すべて セグウェイをはじめとする倒立振子型車両を対象とした 研究である.PMV の車種が異なる場合の検証や，車種 間の比較はできていないのが現状である。また，歩行者 の受容性は歩行者の個人属性によっても異なると考えら れるが，いずれも歩行者の個人属性は考慮していない.

車種間の比較を行うためには，既往研究と同様の被験 者実験を実施し，歩行者に主観評価をさせる方法もある
が，様々な車種を用いて同一環境で実験を行うことは費 用その他の面で困難を伴う。一方，歩行者は外見等の限 られた情報であっても，自らの経験に基づいて車両の特 性を想像し，リスクを評価すると考えた。

そこで本研究では複数の車種の静止画像を用いた 2 回 のアンケート調査を通じて, 各種 PMV への受容性の比 較分析を行った. 2 章では 2 つアアンケート調査の概要 を示す． 3 章ではバーチャルリアリティー（VR）実験被 験者へのアンケート調査, 4 章ではウェブアンケート調 查の分析を行う． 5 章では $2 つ の$ 調査の比較を行う.

\section{2. リスク認知に関するアンケート調査}

\section{（1）リスク認知の知見とアンケートの設計方針}

Slovic ${ }^{10)}$ は，人間の活動や技術から幅広く選定し，遺 伝子工学，ジョギング，犯罪など 90 個のハザードに対 して, アンケート調査を通じてリスク認知構造を分析し た。 因子分析の結果, リスクは未知性(unknown risk), 劦 威性(dreadrisk), 被害曝露人口(degree of exposure to the hazard) の3つの次元に分類された。 人は新たな車両である PMV に対しても類似の構造でリスクを認知するものと想定さ れることから, 本研究でもこの分析に倣ってアンケート 調査を実施した。ただし，本研究で対象とするのは PMV の車種ごとのリスク認知の比較であり, 車両はい ずれも歩行者空間の走行を想定した比較的低速の乗り物 である。したがって，被害曝露人口の車種による違いは ほとんどないと考えられるため，被害曝露人口に関連す る設問は除いた.

また，歩行空間において歩行者にとって致死的な度合 いを問う設問は被験者にとって想像しづらいものである ことから，致死的等の語は用いず，より被験者が理解の しやすい形でアンケート内容を設計した。

\section{(2) 2 つのアンケート調査の概要}

本研究では， 2 つのアンケート調査を行った．概要を 表-1 に示す. PMV が普及したと想定した将来の歩車混 在下では，PMV が歩行者の至近を通過することが想定 される. PMV と共存する空間での歩行者の受容性は, PMV の挙動特性についてある程度知識のある歩行者と そうでない歩行者とで異なると予想される.このため, PMV に関する経験の程度や有無による違いを比較でき るよう 2 種類の被験者に対する調査を行った. 1 つ目は VR による歩行体験後に行うアンケート調査であり，2 つ目はウェブアンケート調査である.VR 実験では，群 衆の中に PMV の一種であるセグウェイが混在する状況 をVR内に実装し，その中を歩行者として移動する実験 を実施し ${ }^{11)}$ ，その後その被験者にアンケート調査を行っ 
た. VR 実験側の時間制約上， 1 車種のみしか実験を行 えなかったことから，比較的認知度の高い PMV である セグウェイを代表的な車種として選択した. ウェブアン ケート調查ではVR体験がない人を対象とした。

VR 実験後アンケートでは, 自転車，セグウェイ，ナ インボット, ホバーボート, シニアカー, ユニカブ (図 -1, 表-2）の 6 車種を対象とした. 車両の選定には, 国 内での認知度が多少あること, PMV の設計速度の大小, 立位・座位のタイプの違いを考慮した. ウェブアンケー トで対象とした車両は，VR 実験後のアンケートでの対 象 6 車種にウィングレットとウィル（図-1，表-2）を加 えた合計 8 車種である.

\section{（3）バーチャルリアリティー実験後のアンケート調査}

VR 環境は，フォーラムエイト社の UC-Win/Road Ver. 12 を用いて生成した. この VR 空間内に，インタラクティ ブに回避することのできるセグウェイと歩行者のモデル を作成し, 群衆とセグウェイの混在空間を生成した. こ の中を歩行する被験者は他の周辺歩行者と同様に扱われ， セグウェイは被験者の動きに応じて回避することができ る.ヘッドマウントディスプレイとして Oculus Rift を装 着した被験者にその VR 空間内を歩行する体験をさせた。 実験は大学の室内で行った. VR の設定の詳細は付録を 参照されたい. このVR 実験後, 対面で記入式のアンケ 一トを実施した. 被験者は 20 歳から 23 歳までの大学生 と大学院生であり, 40 人が参加した.

各 PMV に対するリスク認知に関する設問項目は全て 同じであり，表-3 の通りとした. Q2 は乗り物の怖さを, Q3 は事故の回避性を問うている。，Q4 は，事故によって どの程度被害があるかを予想してもらうものである。

Q5 は操綐性，Q6 は機械制御技術への信頼を問うている. これらの設問は 5 段階評価で答えるようになっている.

また, どのような PMV なら安心できるかを, 歩行者側, 運転手側の立場にたって答える設問も設けた。これらの 設問は5 段階評価で答えることとした．PMVの利用例が わかるように, 想定している利用者層が運転している実 際の写真を見せた。

\section{(4) ウェブアンケート調査}

調査会社への委託により, ウェブアンケート調査を 実施した。被験者は調査会社のモニター登録をしている 者とし，10代，20 代，30 代，40 代，50代，60 代以上の 各年齢層を 50 名ずつ, 計 400 名からの回答を得た. 被験 者には個々の車両の名称は示さず PMV の画像のみ（図1）を見せ，設問に答えてもらうこととした。 これを 8 種類の PMV について繰り返した後, 被験者個人の運 動・運転や性格に関する質問を行った．PMV の画像に は, PMVの車体に棒人間を描きこんだ状態の画像を作
表-1２つのアンケートの概要

\begin{tabular}{|c|c|c|}
\hline & VR実験後アンケート & ウェブアンケート \\
\hline 属性 & 20～23歳の大学 (院) 生 & 17〜 76歳 \\
\hline サンプル数 & 40 & 300 \\
\hline 調査法 & $\begin{array}{l}\text { VR実験後, 対面で記入式の } \\
\text { アンケート }\end{array}$ & WEBアンケート \\
\hline 対象車両 & $\begin{array}{l}\text { 自転車, セグウェイ, ナイ } \\
\text { ンボット, ホバーボート, } \\
\text { シニアカー, ユニカブ }\end{array}$ & $\begin{array}{l}\text { 左記に加えて, ウィング } \\
\text { レット, ウィル }\end{array}$ \\
\hline \multirow{5}{*}{ 設問 } & 年齢, 性別 & 年齢, 性別 \\
\hline & リスク認知に関する設問 & リスク認知に関する設問 \\
\hline & $\begin{array}{l}\text { どのようなPMVなら安心で } \\
\text { きるか (要求性能, 行動) } \\
\end{array}$ & N/A \\
\hline & N/A & $\begin{array}{l}\text { 普段の歩行頻度, 自転車, } \\
\text { バイク, 自動車の運転頻度 }\end{array}$ \\
\hline & N/A & 性格に関する設問 \\
\hline
\end{tabular}

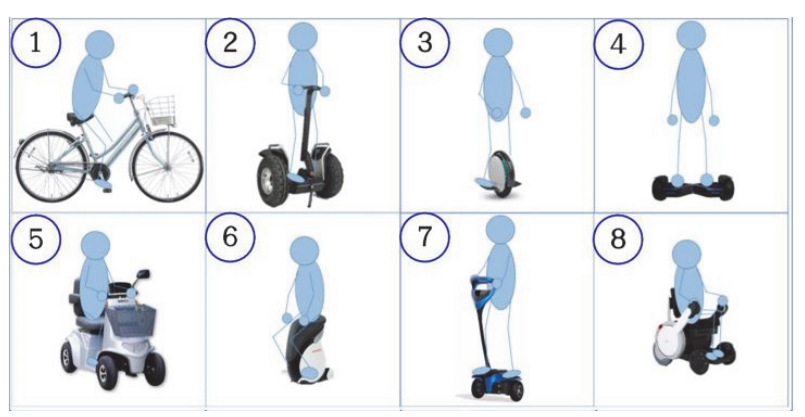

図-1 PMVの写真（ウェブアンケート）

表-2 車種一覧表

\begin{tabular}{|cclll|}
\hline 番号 & 名称 & 乗り方 ハンドル & $\begin{array}{c}\text { 最高速度 } \\
(\mathrm{km} / \mathrm{h})\end{array}$ \\
\hline \hline 1 & 自転車 & 座位 & あり & \\
\hline 2 & セグウェイ & 立位 & あり & 20 \\
\hline 3 & ナインボット & 立位 & なし & 20 \\
\hline 4 & ホバーボート & 立位 & なし & 15 \\
\hline 5 & シニアカー & 座位 & あり & 6 \\
\hline 6 & ユニカブ & 座位 & なし & 6 \\
\hline 7 & ウィングレット & 立位 & あり & 6 \\
\hline 8 & ウイル & 座位 & あり & 6 \\
\hline
\end{tabular}

※最高速度はカタログ值による

成し用いた。 これは運転している人間の年齢や性別, 態 度などを暗示させないためである，なお，車両の名称や 特徴などの詳細をまとめた一覧は表-2 に記載した。 この 情報は被験者に与えていない。

各 PMV に対するリスク認知に関する設問項目は全て 同じであり，表-3の通りとした，Q2から Q5 は VR 実験 後アンケートと同一である。 Q7 は見た目の速度, Q8は 乗り物が予測できない動きをするか，予測性を問うてい る. Q9 は操縦可能になるまでの難易度を予想してもら っている.これらの設問は 5 段階評価で答えるようにな っている.

普段の歩行頻度や，「急いでいれば多少人に接触する 可能性があってもほかの歩行者の間をぬってあるこうと するか」という性格を尋ねる質問もした。 
表-3 リスク認知に関する設問

\begin{tabular}{|c|c|c|c|}
\hline 設問番号 & 設問の意図 & VR実験後アンケートの設問文 & ウェブアンケートの設問文 \\
\hline \multirow[b]{2}{*}{ Q1 } & \multirow[b]{2}{*}{ （認知度） } & \multirow[b]{2}{*}{ この乗り物を知っていますか } & 図の乗り物に人が乗っているところを見たことがありますか. （※） \\
\hline & & & $\begin{array}{c}\text { 選択肢 : 乗ったことがある/実際に目で見たことがある/動画でみたことがある/静止画 } \\
\text { 像でみたことがある/名前を聞いたことがある/該当なし }\end{array}$ \\
\hline Q2 & (怖さ) & この乗り物は怖い & 自分が歩いているすぐ横を図の乗り物が通り抜けるとき，怖いと感゙ますか. \\
\hline Q3 & (回避性) & 自分が気をつけていれば事故を回避できる & 自分が気をつけていれば，図の乗り物との事故を回避できそうだと思いますか. \\
\hline Q4 & （被害程度） & もし事故が起きたら被害は大きい & 歩行者である自分が，図の乗り物とぶつかったとします. 被害は大きいと思いますか. \\
\hline Q5 & （操縦性） & 乗つている人は乗り物をうまく操縦できる & 乗つている人は図の乗り物をうまく操縦できそうだと思いますか. \\
\hline Q6 & (技術信頼性) & 乗り物を制御する技術は信頼できる & N/A \\
\hline Q7 & （想定速度） & N/A & 図の乗り物は速そうだと思いますか. \\
\hline Q8 & （非予測性） & $\mathrm{N} / \mathrm{A}$ & 図の乗り物は予測できない動きをしそうだと思いますか. \\
\hline Q9 & (特別な技能) & N/A & $\begin{array}{l}\text { 図の乗り物に全く乗つたことがない人が乗れるようになるためには，特別な技能の習得 } \\
\text { が必要そうだ思いますか. }\end{array}$ \\
\hline
\end{tabular}

\begin{tabular}{|cllcc|}
\hline \multicolumn{1}{c|}{ 質問 } & 向上しない & 向上する & 標準偏差 & $\mathrm{n}$ \\
\hline 歩道の端を走行する & 4.39 & 0.86 & 38 \\
「通ります」「すみません」などと声をかける & 4.10 & & 0.96 & 40 \\
自転車のベルのようにアラームを鳴らす & 3.15 & & 1.09 & 40 \\
\hline
\end{tabular}

図-2 セグウェイ運転者の行動による歩行者の安心感の向上度平均值

\begin{tabular}{|c|c|c|c|c|c|}
\hline 質問 & 歩行者視点 & \multirow{2}{*}{$\begin{array}{l}\text { 標準 } \\
\text { 偏差 }\end{array}$} & \multicolumn{2}{|c|}{ 運転者視点 } & \\
\hline 周囲の混み具合・歩行者の密度に合わせて速度を制限する & 向上 & & 向上しない & 向上する偏差 & \\
\hline 歩行者に近づくと減脨する & 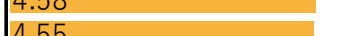 & $0.6 /$ & 4.08 & ** 0.98 & 40 \\
\hline 歩渞の幅に合わ甘て凁度を制限す万 & & 0.14 & 14.33 & 1.10 & 10 \\
\hline & 4.48 & 0.71 & 3.80 & ** 0.82 & +0 \\
\hline 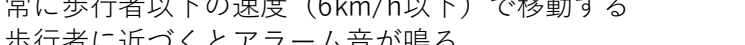 & 2.95 & 1.08 & 2.69 & 1.30 & 39 \\
\hline 歩行者に近づくとアラーム音が鳴る & 2.78 & 1.38 & 3.05 & 1.28 & 40 \\
\hline
\end{tabular}

図-3 セグウェイに対する要求機能と安心感の向上度平均值

\section{3. バーチャルリアリティー実験後のアンケート} 調査の分析

\section{(1) 基礎集計}

\section{a) 歩行者の要望としての要求性能}

VR 実験後アンケートでは, まず VR でのセグウェイ 回避体験を踏まえて，安心感を向上させるための運転者 の行動や機器の要求性能について尋ねた. 図-2は, セグ ウェイの運転者の行動による歩行者の安心感の向上の有 無の平均值を示したものである. 安心感は 1 点（向上し ない）から 5 点（向上する）までの 5 段階で評価した. 歩道の端を走行するなど，運転者側が歩行者に対して譲 る行動を取るものが高評価であった．歩行者に注意を促 寸行動では，運転者による声掛けよりも警告音の方が低 評価であった。

セグウェイに存在したとしたら安心感が向上する機能 を，歩行者と運転者それぞれの視点から評価してもらっ た結果を図-3に示寸．歩行者の視点からは「周囲の混み 具合・歩行者の密度に合わせて速度を制限寸る」「歩行 者に近づくと減速する」「歩道の幅に合わせて速度を制
限する」といった，周囲の状況に応じた速度制限が高評 価であった．しかしセグウェイの運転者の視点に立つと， 歩行者視点の場合に比べて有意水準 $1 \%$ 「周囲の混み 具合・歩行者の密度に合わせて速度を減速する」「歩道 の幅に合わせて速度を制限する」の評価が下がっている. また，一律に速度を $6 \mathrm{~km} / \mathrm{h}$ 以下に抑えるといった機能は 他に比べて低評価であった。 これは運転者の利便性を不 必要に低下させるものであるからだと推察できる，その 他自由記述では, 自動ブレーキや転倒防止機能を挙げる 被験者が多数いた.

\section{b) 歩行者の PMVに対するリスク認知}

リスク認知に関する設問ごとの平均值を図-4に示す. 立位タイプは座位タイプに比べて，「怖い」「回避でき ない」「事故の際に被害は大きい」「操縦はうまくなさ そう」「機械に信頼できない」と認識される傾向がある. また，表-4 に設問間の相関係数行列を示す，Q5（操縦 性) と Q6（技術信頼性）は相関係数 0.70 となり, 強い 正の相関がみられた．信頼できる技術の乗り物に対して， 操縦者はうまく乗れると認識されているなど, 技術と操 縦者への信頼は一体的に捉えている可能性がある. 


\begin{tabular}{|c|c|c|c|}
\hline 質問 & 車種 & 平均值 & \\
\hline $\begin{array}{c}\text { Q1 } \\
\text { （認知度） }\end{array}$ & $\begin{array}{ll}1 & \text { 自転車 } \\
2 & \text { セグウェイ } \\
3 & \text { ナインホット } \\
4 & \text { ホバーボート } \\
5 & \text { シニアカー } \\
6 & \text { ユニカブ }\end{array}$ & $\begin{array}{l}5.0 \\
4.9 \\
1.7 \\
3.7 \\
4.6 \\
1.6\end{array}$ & $\begin{array}{l}0.00 \\
1.38 \\
1.23 \\
0.88 \\
0.98 \\
0.96\end{array}$ \\
\hline $\begin{array}{c}\text { Q2 } \\
\text { （怖さ） }\end{array}$ & $\begin{array}{ll}1 & \text { 自転車 } \\
2 & \text { セグウェイ } \\
3 & \text { ナンホホシット } \\
4 & \text { ホバーボート } \\
5 & \text { シニアカーー }\end{array}$ & $\begin{array}{l}2.7 \\
3.1 \\
3.4 \\
3.0 \\
1.9 \\
2.2\end{array}$ & $\begin{array}{l}1.01 \\
1.22 \\
1.12 \\
1.41 \\
1.28 \\
1.15\end{array}$ \\
\hline $\begin{array}{c}\text { Q3 } \\
\text { （回避性） }\end{array}$ & $\begin{array}{ll}1 & \text { 自転車 } \\
2 & \text { †グイイ } \\
3 & \text { ナインボット } \\
4 & \text { ホバーボート } \\
5 & \text { ジアカー } \\
6 & \text { ユニカブ }\end{array}$ & $\begin{array}{l}3.3 \\
3.3 \\
2.8 \\
3.0 \\
4.0 \\
3.7\end{array}$ & $\begin{array}{l}0.30 \\
1.13 \\
1.13 \\
1.21 \\
1.06 \\
1.14\end{array}$ \\
\hline $\begin{array}{c}\text { Q4 } \\
\text { (被害程度) }\end{array}$ & $\begin{array}{ll}1 & \text { 自転車 } \\
2 & \text { セグウェイ } \\
3 & \text { ナインホットト } \\
4 & \text { ホバーボート } \\
5 & \text { シニアカー } \\
6 & \text { ユニカブ }\end{array}$ & $\begin{array}{l}4.3 \\
3.3 \\
3.2 \\
2.9 \\
3.0 \\
2.4\end{array}$ & $\begin{array}{l}1.14 \\
1.21 \\
1.11 \\
0.92 \\
1.32 \\
0.94 \\
0.99\end{array}$ \\
\hline $\begin{array}{c}\text { Q5 } \\
\text { （操縦性） }\end{array}$ & $\begin{array}{ll}1 & \text { 自転車 } \\
2 & \text { セグウェイ } \\
3 & \text { ナインボット } \\
4 & \text { ホバーボート } \\
5 & \text { シニアカー } \\
6 & \text { ユニカブ }\end{array}$ & $\begin{array}{l}3.9 \\
2.5 \\
2.1 \\
2.4 \\
3.1 \\
3.0\end{array}$ & $\begin{array}{l}1.58 \\
1.33 \\
1.10 \\
1.21 \\
1.00 \\
1.01\end{array}$ \\
\hline $\begin{array}{c}\text { Q6 } \\
\text { （技術信頼性） }\end{array}$ & $\begin{array}{ll}1 & \text { 自転車 } \\
2 & \text { †グイイ } \\
3 & \text { ナインボット } \\
4 & \text { ホバーボート } \\
5 & \text { シニアカー } \\
6 & \text { ユニカブ }\end{array}$ & $\begin{array}{l}3.6 \\
2.7 \\
2.2 \\
2.5 \\
3.4 \\
3.1\end{array}$ & $\begin{array}{l}1.30 \\
1.25 \\
1.05 \\
1.13 \\
0.99 \\
0.99\end{array}$ \\
\hline \multicolumn{4}{|c|}{ ※青: 自転車, 緑: 立位タイプPMV, 黄: 座位タイプPMV } \\
\hline
\end{tabular}

図-4 リスク認知に関する設問の回答平均值（VR実験後 アンケート)

\section{(2) 因子分析}

6 つのリスク認知に関する設問を用いて因子分析を行 つた．表-5はこの結果を示したものである．分析には青 木の関数 (factanal2 関数) 12)を用いた. 第一因子に Q1, Q5，Q6 が，第二因子に Q2，Q3，Q4 が強く寄与してい る. 第一因子は「この乗り物をあまり知らない」「乗っ ている人は乗り物をうまく操縦できない」，「乗り物を 制御する技術は信頼できない」といった未知性，制御不 安定性，非信頼性を表していると推測され，これを非信 頼性因子と名付ける。 また，第二因子は「この乗り物は 怖い」，「自分が気をつけていても事故を回避できな い」，「もし事故が起きたら被害は大きい」といった外 敵性，危険性を表していると推測され，これを危険性因 子と名付ける.

これらの因子は，Slovicにおける未知性(unknown risk)と 劦威性(dread risk)にそれぞれ対応すると考えられる. そ こで Slovic と同様に，リスク認知マッピングを行う. 変 数ごとに標準化した回答值 $D$, 因子負荷量 $L$ と相関係数 $R$ を用い，因子得点 $Z$ を計算した．計算方法は，以下の とおりである。

$$
Z=D\left(R^{-1} L\right)
$$

この因子得点の平均值を，第一因子（非信頼性）軸を $y$ 軸に，第二因子（危険性）軸を $x$ 軸にとつて，車種ご とにプロットしたのが図-5である，得点分布は座位タイ プ PMV（ユニカブとシニアカー），立位タイプ PMV
表-4 相関係数行列（VR実験後アンケート）

\begin{tabular}{|c|c|c|c|c|c|c|c|}
\hline & & Q1 & Q2 & Q3 & Q4 & Q5 & Q6 \\
\hline Q1 & 認知度 & 1.00 & & & & & \\
\hline Q2 & 怖さ & -0.10 & 1.00 & & & & \\
\hline Q3 & 回避性 & 0.05 & -0.52 & 1.00 & & & \\
\hline Q4 & $\begin{array}{l}\text { 被害 } \\
\text { 程度 }\end{array}$ & 0.17 & 0.49 & -0.28 & 1.00 & & \\
\hline Q5 & 操縦性 & 0.25 & -0.34 & 0.25 & -0.04 & 1.00 & \\
\hline Q6 & $\begin{array}{c}\text { 技術 } \\
\text { 信頼性 }\end{array}$ & 0.24 & -0.32 & 0.33 & -0.16 & 0.70 & 1.00 \\
\hline
\end{tabular}

表-5 因子負荷量（VR実験後アンケート）

\begin{tabular}{|cc|c|c|}
\hline Q1 & 認知度 & $\begin{array}{c}\text { 第一因子 } \\
\text { (非信頼性) }\end{array}$ & $\begin{array}{c}\text { 第二因子 } \\
\text { (危険性) }\end{array}$ \\
\hline Q2 & 怖さ & -0.31 & 0.01 \\
\hline Q3 & 回避性 & -0.19 & 0.84 \\
\hline Q4 & 被害程度 & -0.06 & -0.56 \\
\hline Q5 & 操縦性 & -0.89 & 0.60 \\
\hline Q6 & 技術信頼性 & -0.74 & -0.17 \\
\hline \multicolumn{2}{|c|}{ 寄与率 } & 0.25 & -0.23 \\
\hline
\end{tabular}

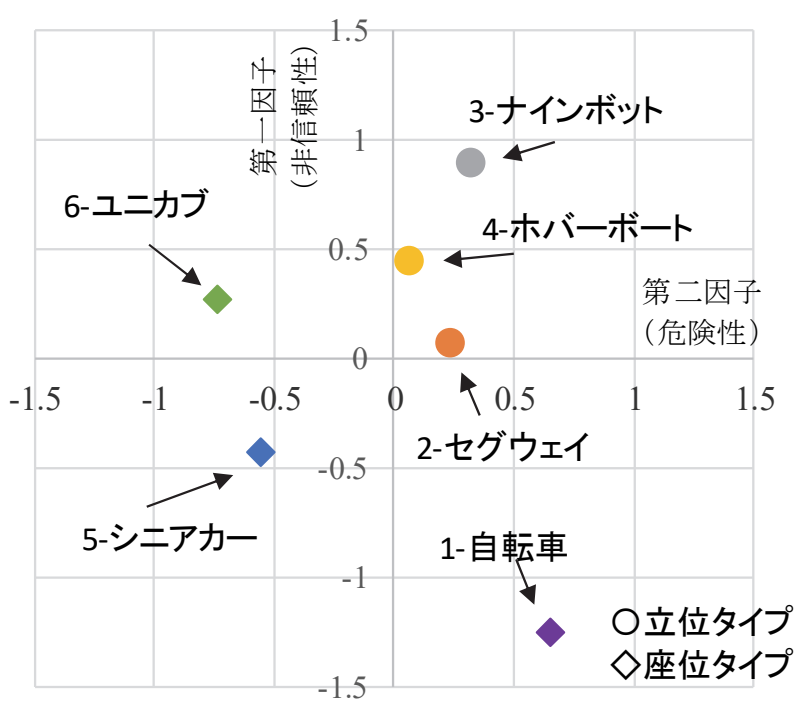

図-5 因子得点の車種別平均值（VR実験後アンケート）

（セグウェイ，ナインボット，ホバーボート）と自転車 の 3 つに大まかに分けることができ，このうち座位タイ プは立位タイプより第二因子（危険性）が小さくなり， リスクが小さく評価される傾向がある．立位タイプ座位 タイプともにいずれも自転車よりも危険性は低く認知さ れているが，自転車ほど信頼度は高くないことがわかる. 


\section{4. ウェブアンケート調査の分析}

\section{(1) 基礎集計}

\section{a) PMV の認知度}

ウェブアンケート調查における設問 Q1 の回答結果か

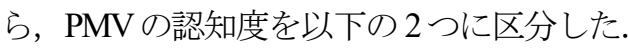

「認知度 : 高」：実際に乗ったことがあったり見たりし たことがある，もしくは動画で見たことがある

「認知度 : 低」：上記に該当しない

図-6に車種ごとの認知度を示寸。認知度は, 自転車, シニアカー，セグウェイ，ウィングレット，ホバーボー ト，ナインボット，ウィルの順に小さくなった．自転車， シニアカー, セグウェイは過半数の被験者に認知されて いた.

\section{b) 歩行者のPMVに対するリスク認知}

VR 実験後アンケートと同様に, ウェブアンケートで のリスク認知に関する設問の回答を分析した．設問ごと の平均值を図-7 に示す．立位タイプは座位タイプに比べ て，「怖い」「回避できない」「操縦はうまくなさそう」 「速そう」「予測できない動きをしそう」「特別な技能 が必要だ」と認識されている. 個別の乗り物間の比較を すると，ナインボットとホバーボートはどの設問でもほ とんど同じ平均值である. セグウェイとウィングレット も同様である．シニアカーとウィルは，傾向としては同 じであるが，シニアカーの方がより安全側の回答が多か った.

Q3（回避性）では，シニアカーとの事故を最も回避 できるが，ナインボットとの事故を最も回避できないと 認識されている。これは PMV の認知度（図-6）の大小 に応じているように思われる.よく知らなければ回避し ようがないと認識された可能性がある，Q8（非予測性） では，シニアカーとウィルは予測できない動きはしなさ そうだと認識されているものの，ほかの PMV は挙動が 予想できないと認識されている。これは車い寸タイプの PMVであれば，既存の電動車い寸などから動きを類推

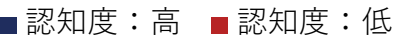

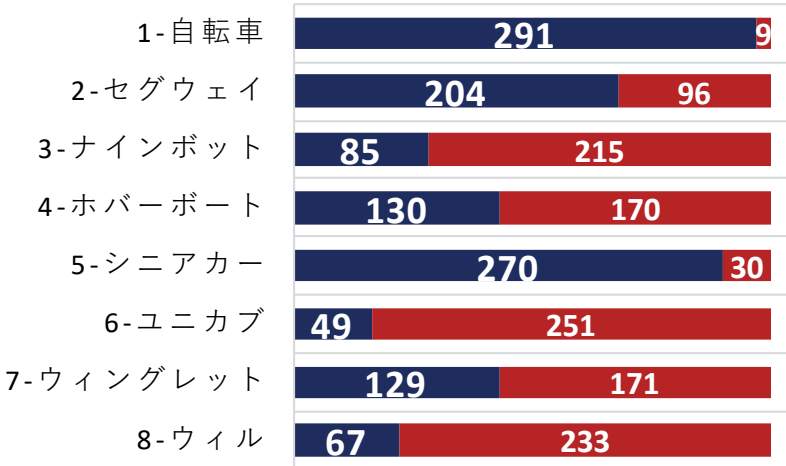

図-6 PMV の認知度（ウェブアンケート）
しやすいことが関係していると思われる．また，表-6に 相関係数行列を示寸．VR 実験後アンケートと同一の質 問では類似の結果となった。ウェブアンケートで追加し た設問については，Q8（非予測性）と Q9（特別な技能） に正の相関がみられることから，動きが容易に予測でき ない乗り物は，運転にも特別な技能が必要だと考えるな

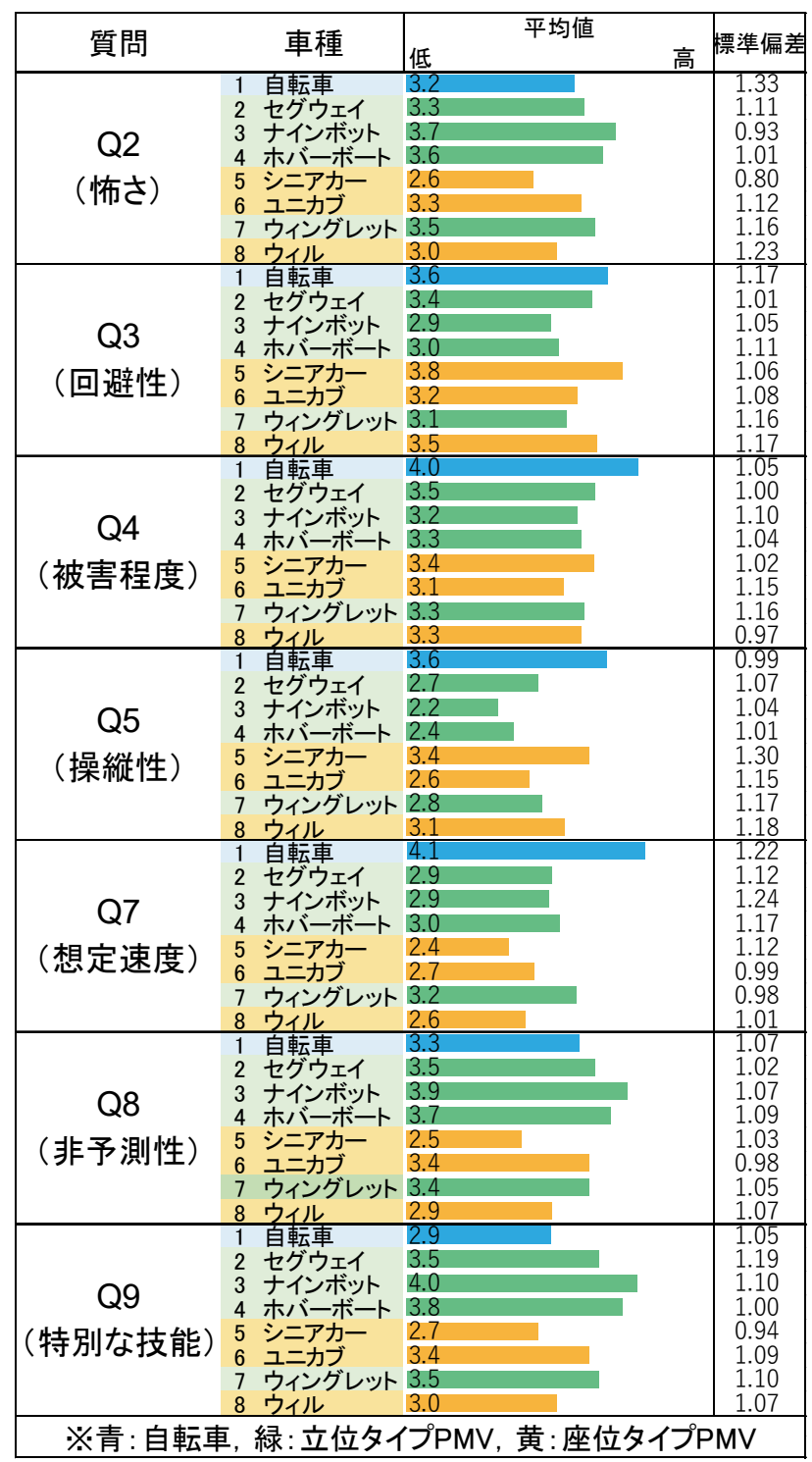

図-7 リスク認知に関する設問の平均值（ウェブアンケート）

表-6 相関係数行列（ウェブアンケート）

\begin{tabular}{|lc|rrrrrrr|}
\hline & & Q2 & Q3 & Q4 & Q5 & Q7 & Q8 & Q9 \\
\hline Q2 & 怖さ & 1.00 & & & & & & \\
Q3 & 回避性 & -0.51 & 1.00 & & & & & \\
Q4 & 被害程度 & 0.45 & -0.29 & 1.00 & & & & \\
Q5 & 操縦性 & -0.41 & 0.47 & -0.08 & 1.00 & & & \\
Q7 & 想定速度 & 0.40 & -0.28 & 0.47 & -0.04 & 1.00 & & \\
Q8 & 非予測性 & 0.51 & -0.43 & 0.33 & -0.48 & 0.35 & 1.00 & \\
Q9 特別な技能 & 0.38 & -0.30 & 0.20 & -0.37 & 0.21 & 0.46 & 1.00 \\
\hline
\end{tabular}


表-7 因子負荷量（ウェブアンケート）

\begin{tabular}{|cc|c|c|}
\hline & 設問 & $\begin{array}{c}\text { 第一因子 } \\
\text { (非信頼性) }\end{array}$ & $\begin{array}{c}\text { 第二因子 } \\
\text { (危険性) }\end{array}$ \\
\hline \hline Q2 & 怖さ & 0.55 & 0.52 \\
\hline Q3 & 回避性 & -0.58 & -0.30 \\
\hline Q4 & 被害程度 & 0.16 & 0.67 \\
\hline Q5 & 操縦性 & -0.83 & 0.08 \\
\hline Q7 & 想定速度 & 0.12 & 0.68 \\
\hline Q8 & 非予測性 & 0.62 & 0.36 \\
\hline Q9 & 特別な技能 & 0.49 & 0.22 \\
\hline \hline & 寄与率 & 0.28 & 0.21 \\
\hline
\end{tabular}

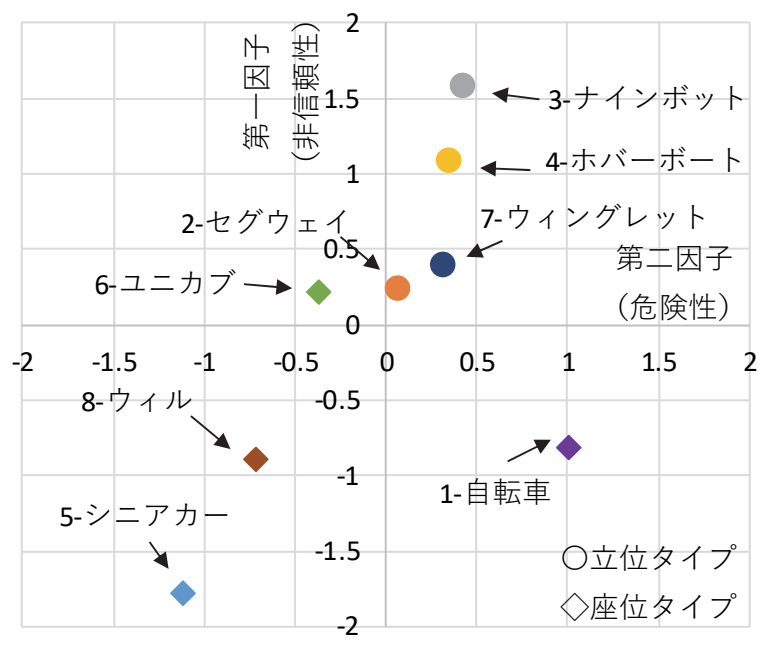

図-8 因子得点の車種別平均值（ウェブアンケート）

ど，概ね妥当な傾向がみられる.

\section{(2) 因子分析}

VR 実験後のアンケート調査の結果の分析と同様に, ウェブアンケート調査の因子分析を行った. リスク認知 に関する設問のうち，PMV の認知度に関する設問を除 く 7 つの設問 Q2-Q5，Q7-Q9 を因子分析に用いた. 表-7 に算出された因子負荷量を示した。第一因子に Q2, Q3, Q5,Q8,Q9 が，第二因子に Q2,Q4,Q7 が分類されることが 分かる. VR 実験後アンケートと同様に，非信頼性と危 険性の 2 軸に対応していると解釈できる.

この因子得点を，第一因子（非信頼性）軸を $y$ 軸に， 第二因子 (仜険性) 軸を $x$ 軸にとって，リスク認知マッ ピングを行った（図-8）。全体の傾向は VR 実験後アン ケートと類似しており，座位は立位タイプよりリスク評 価が小さい傾向がある，立位・座位タイプともに自転車 よりも危険性は低く認知されている。また，立位・座位 タイプのそれぞれの中でも，ハンドルが付いているタイ プの PMVはハンドルが付いていないタイプの PMVに比 ベて，リスクが小さく評価されている。 ハンドルのある 方は，制御が容易に見え，安心できるのだろう。

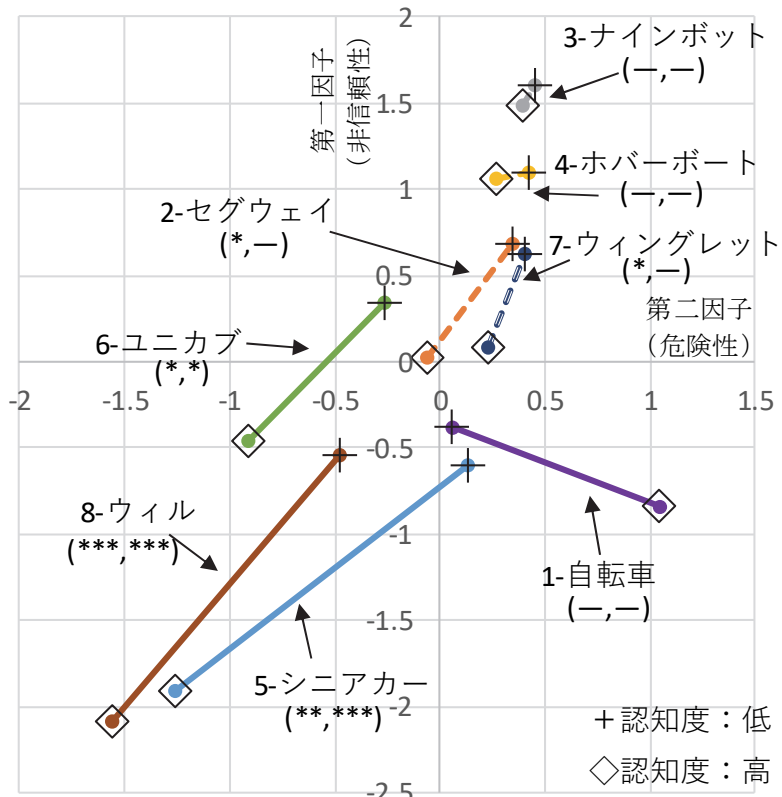

（第一因子の検定結果，第二因子の検定結果）

$*$ :有意水準 $5 \%, * *$ :有意水準 $1 \%, * * *$ :有意水準 $0.5 \%$

図-9 認知度ごとの因子得点の車種別平均值

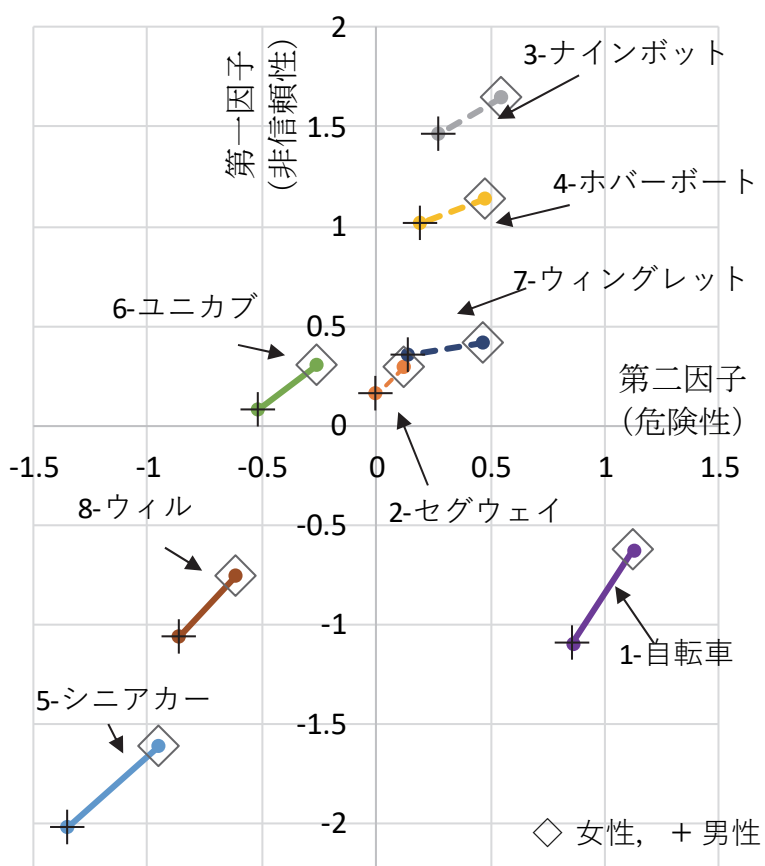

※各因子得点は有意水準 $5 \%$ で有意差なし

図-10 性別ごとの因子得点の車種別平均值

\section{a) 認知度によるリスク評価の違い}

車種ごとに認知度 : 高と認知度 : 低にわけ，因子得点 を求めたものを図-9に示す。自転車の認知度 : 低はサン

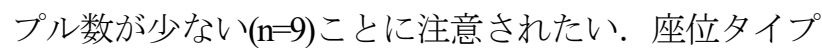
PMV は，認知度が高いと第一因子（非信頼性）と第二 因子（危険性）ともに得点が $5 \%$ 有意に増加している. ハンドルつき立位タイプ PMV は，認知度が高いと，第 一因子（非信頼性）の得点が 5\%有意に増加している。 


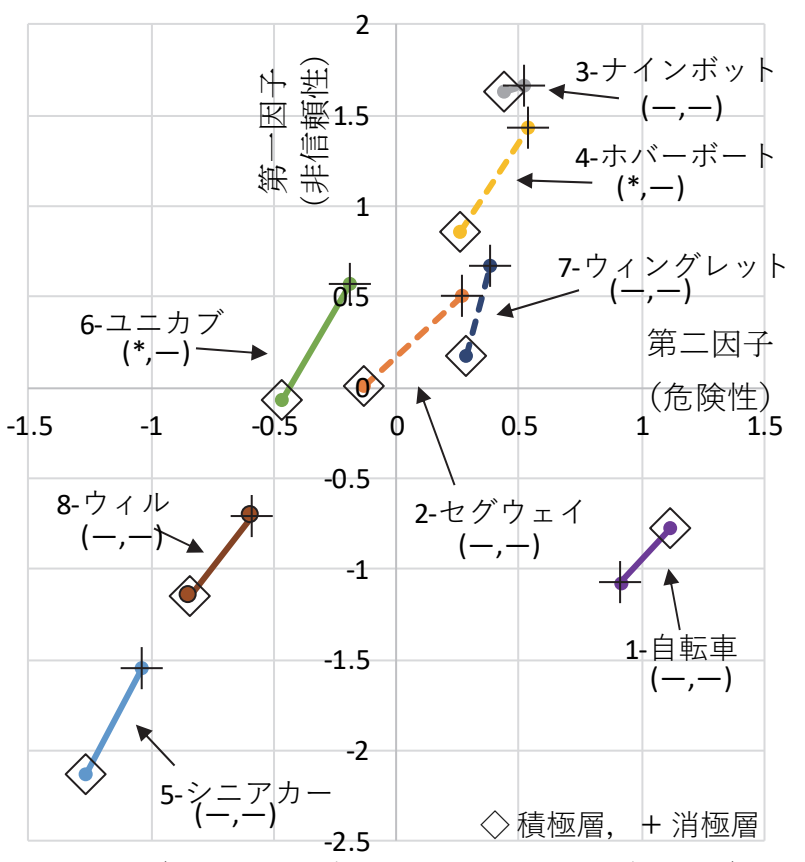

（第一因子の検定結果，第二因子の検定結果）

*:有意水準 $5 \%, * *$ : 有意水準 $1 \%, * * *$ :有意水準

図-11 性格ごとの因子得点の車種別平均值

それに対して，ハンドルなし立位タイプ PMV の評価は， 5\%で有意には異なるといえない。このことから，認知 度が高いほど, 特に座位タイプ PMV のリスクを小さく 評価していることがわかる.

\section{b）性別によるリスク評価の違い}

男性 $(\mathrm{n}=126)$ と女性 $(\mathrm{n}=174)$ にわけ，因子得点を求めたも のを図-10 に示寸，男性はリスクを小さく評価し，女性 はリスクを大きく評価する傾向があったが有意水準 5\% で有意ではなかった.

\section{c）性格によるリスク評価の違い}

設問「急いでいれば，多少人に接触する可能性があっ てもほかの歩行者の間をぬって歩こうとしますか.」を 積極層「（どちらかといえば）そう思う」（n=155）, 中立層「どちらともいえない」 $(\mathrm{n}=42)$ ，消極層「（ど ちらかといえば）そう思わない」（n=103）の 3 階級に わけ，そのうち中立層を除き，積極層と消極層で因子得 点を求めたものを図-11 に示す. 自転車とナインボット を除く PMV は積極的な歩行者にとってリスクを比較的 小さく評価する傾向がみられるが，ユニカブとホバーボ 一トのみ，有意水準 5\%で第一因子（非信頼性）が小さ くなった，一方で，自転車は傾向が逆であるが，有意水 準 5\%で有意差はみられなかった。

\section{d) 普段の歩行頻度によるリスク評価の違い}

設問「普段一日当たり外で何分くらい歩きますか」の 回答者を 10 分以下 $(\mathrm{n}=74), 10$ 分以上 1 時間未満 $(\mathrm{n}=193) ， 1$ 時間以上（n=33）の 3 階級にわけ，因子得 点を求めたものを図-12 に示す. どの車種の因子得点の 平均值も有意水準 $5 \%$ で有意差は見られなかったものの,

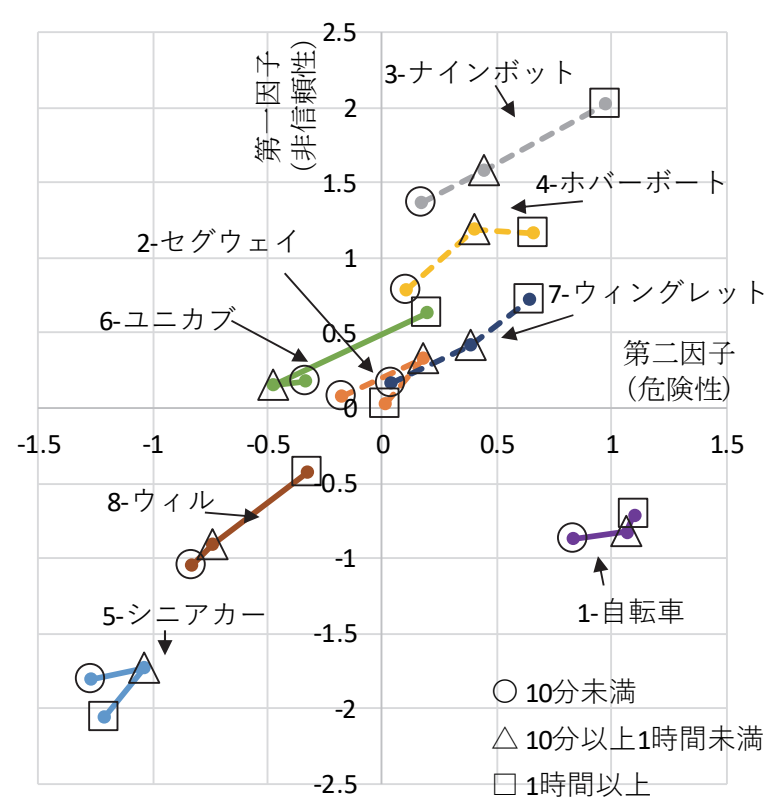

※各因子得点は有意水準 $5 \%$ で有意差なし

図-12 歩行頻度ごとの因子得点の車種別平均值

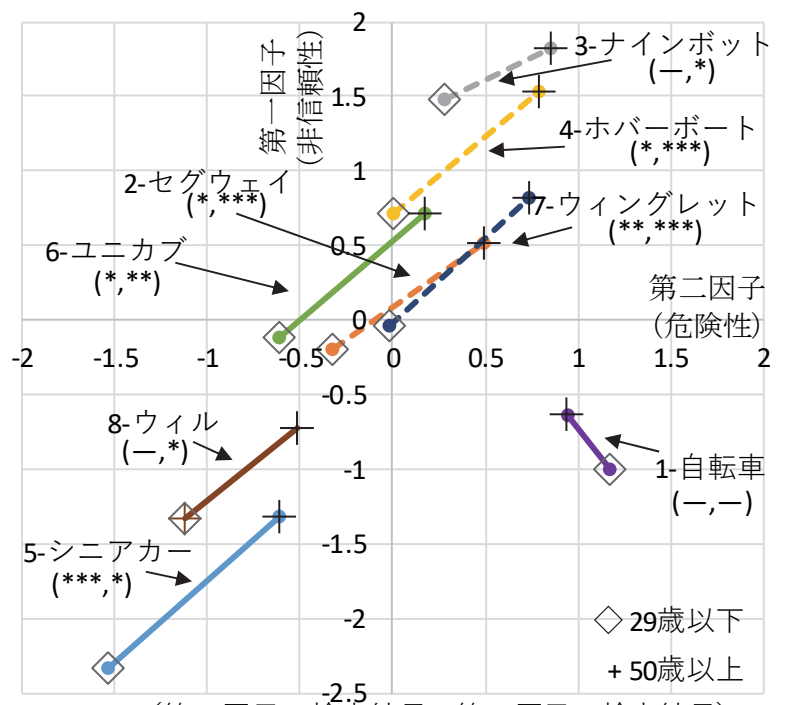

（第一因子の検定結果，第二因子の検定結果）

$*$ : 有意水準 $5 \%, * *$ : 有意水準 $1 \%, * * *$ : 有意水準 $0.5 \%$

図-13 年齢ごとの因子得点の車種別平均值

よく歩く人ほどリスクを大きく, 歩かない人ほどリスク を小さく評価する傾向がみられる，これは，歩行機会が 多い人ほど PMV の普及時に実際に交錯する機会が高く なるためと考えられる.

\section{e）年齢によるリスク評価の違い}

年齢を 29 歳以下 $(n=100), 30$ 歳以上 49 歳以下 $(\mathrm{n}=100), 50$ 歳以上 $(\mathrm{n}=100)$ の 3 階級にわけ, 因子得 点を求めたものを図-13 に示す. 50 歳以上の歩行者（壮 年層）は 29 歳以下（若年層）に比べて, 自転車以外の 車両全てに対して第二因子（危険性）が有意水準 5\%で 有意に大きくなった. ナインボット, ウィル，自転車を のぞくPMV に対して，第一因子（非信頼性）が有意水 
準 5\%で有意に大きくなった．全体として自転車以外の リスクを大きく評価する傾向だった。自転車は各設問で 世代間に違いがあまり見られない。

PMV 全般に対して, 壮年層と比べて若年層は, Q3 （回避性），Q4（被害程度），Q7（想定速度），Q9 (特別な技能) の4つの設問において，5\%有意に平均值 の差があった. 若年層にとって PMV は回避しやすく, 事故時の被害も小さく, 速度も遅く, 運転に特別な技能 を必要としない乗り物だという認識が形成されている. 結果として, 若年層にとって PMV のリスクは小さく, 壮年層にとって PMV のリスクは大きいという世代間で の認識格差が発生していると考えられる.

\section{2 つのアンケート調査の比較分析}

VR 実験では，セグウェイの挙動を VR 空間上で再現 し，被験者に歩行者側の体験を繰り返しさせた．さらに， もともとセグウェイの乗車経験がある被験者が半数を占 めていた. 一方ウェブアンケート被験者は PMV の乗車 経験のない人が多数である.このような被験者特性を考 えると，2つのアンケートの回答を比較することで，VR 体験が社会的受容性の向上に与える影響を考察できると 考えられる.

VR 実験後アンケートの被験者 $(\mathrm{n}=40)$ は 20 代前半の人 で構成されているため, ウェブアンケートの被験者のう ち 29 歳以下 $(\mathrm{n}=100)$ のンプルとの間で回答結果を比較 したものを図-14に示す．なお，2つのアンケートで設問 文の文章表現が若干変化しているが，同一の質問意図で あり，結果への影響は小さいものと考えられる.

全体の結果として，回答のばらつきが大きく，いずれ も統計的に有意な差は見られなかった，立位タイプであ るセグウェイやナインボットはアンケート間で差があま り見られない，VR 実験の被験者は，セグウェイの走行 特性を理解し，危険性を認識し，信頼性が向上するとい う仮説を立てたが，傾向を確認するに至らなかった．座 位タイプのシニアカーの Q2（怖さ）で比較的大きな差 を見せている. 提示した写真の違いの影響を否定できな いが，VR 実験後アンケートでは，立位タイプのリスク を再認識した上でセグウェイの挙動に慣れたことと, 座 位タイプの方が高さを低く抑えられていることによって, リスクが低く再評価され, 安心感がより向上したと評価 した可能性がある.

\section{6. おわりに}

次世代のモビリティとして期待される PMV の導入に

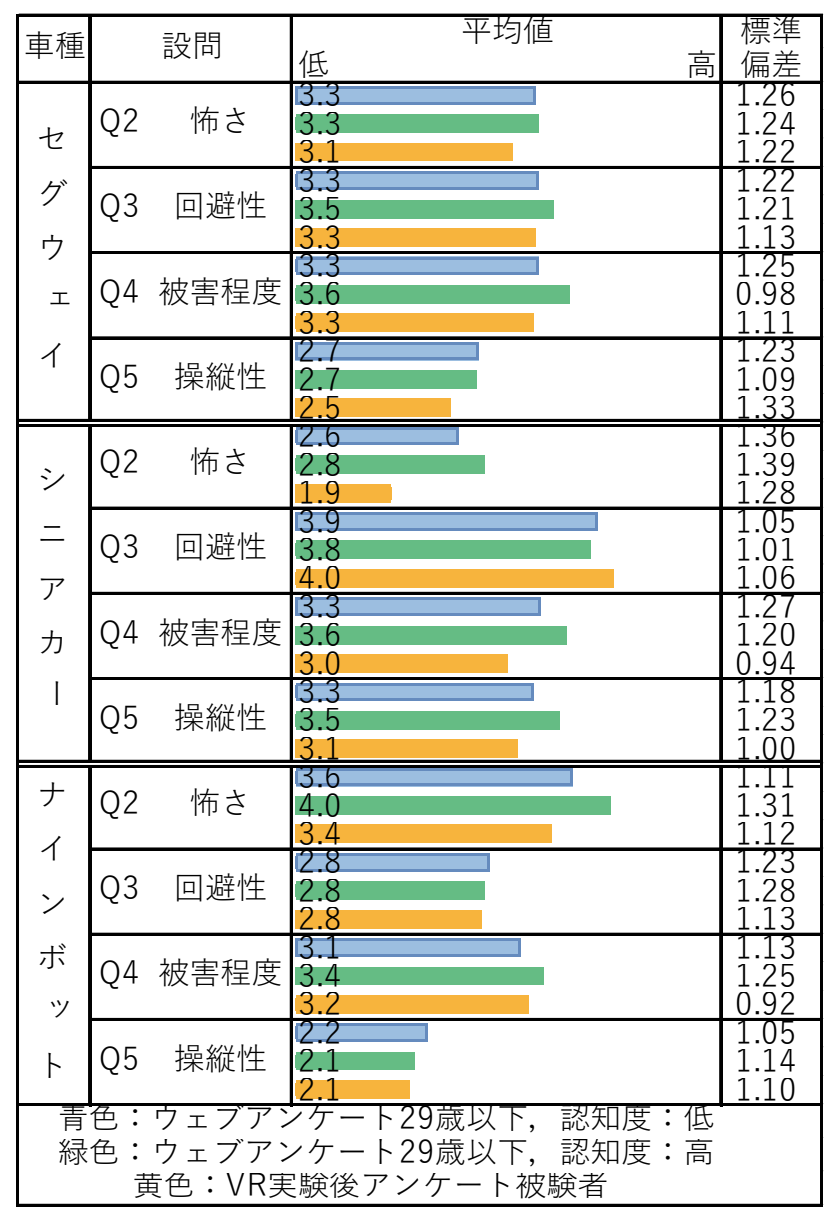

図-14 2つのアンケート間の回答平均值の比較

際しては，周辺歩行者からの社会的受容性を高めること が求められる. そこで歩行者の様々な PMV に対寸るリ スク認知をアンケートにより調査した. 因子分析の結果, 歩行者の PMV に対するリスク構造は非信頼性と危険性 の 2 つ次元にまとめられた.

PMV の車種のうち, 座位タイプは立位タイプに比心゙ て，安全で信頼がおけるとみなされ，リスクが小さく認 知されることが明らかになった. 同様に, ハンドルのつ いているタイプはついていないタイプに比べて, リスク が小さく認知されていることが明らかになった.

一方, 歩行者の属性による違いの1つとして, PMVに 対する認知度がある. 認知度が高い（挙動を見たことが ある）場合に比べて，認知度が低い（PMV の挙動を見 たことがない）と，座位タイプ，ハンドル付き立位タイ プPMVの順にリスクを大きく評価する.

社会的受容性を高めるために，危険性と非信頼性の 2 つの次元でのリスクを下げる必要がある. 本研究では, 認知度を高めることによって, 座位タイプ PMV の危険 性と非信頼性の 2 つ次元ともにリスクを下げられる可 能性があることを示した，また，ハンドルつき立位タ イプ PMV は, 非信頼性の 1 次元のリスクを下げられる 可能性があることを示した.

本研究では, 立位タイプ PMV の普及に先駆けて市民 
が VRなど映像体験を重ねることで，PMVの挙動を正確 に理解してもらい，社会的受容を形成することが可能だ と考え，2 種類のアンケート調査を比較したが，有意な 変化が見受けられなかった.

その他にも，歩行者の属性による以下の違いが明らか になった.

・急いでいるときに人込みの中を積極的に進むことに 消極的な歩行者は, 積極的な歩行者に比べて PMV へのリスクを大きく評価する.

・ 壮年層は若年層に比べて, PMV へのリスクを大き く評価する.

本研究では有意差がみられなかったが，以下の傾向も 見られた。

・ 女性は男性に比べて PMV へのリスクを大きく評価 寸る可能性がある.

・日頃よく歩く人ほど, PMV へのリスクを大きく評 価する可能性がある.

本研究では，あくまで静止画による PMV の印象を尋 ねたため，PMV を実際に見たり乗車したりすることに よってリスク認知がどのように変わるかを明らかにする 必要がある．また，衝突危険性に関する客観性指標やリ スク認知以外の主観的危険度指標との関連性を明らかに することも今後の課題である.

謝辞 : 本研究は, 科学研究費補助金（16K14317 および 17K18947），(公社)日本交通政策研究会による助成を受 けた成果の一部である.ここに記して謝意を表する。

\section{付録 VR 実験の詳細}

VR実験の詳細を示すＶRR実験は，大学の室内で実施 し，VRヘッドセットはOculusRiftを使用した. 映し出し た映像はUCwin-roadを用いて生成した空間内をセグウェ イと歩行者が移動するようになっている（図-15, 図16) .

\section{（1） キャラクタの挙動設定}

キャラクタの移動軌跡の計算には，歩行者が他の歩行 者や障害物から受ける心理的な仮想上の反力(Social Force)を用いた歩行モデルを基本に，これを修正したモ デル13)を使用した．セグウェイのモデルパラメータは走 行実験に基づき推定したもののを用いた。

\section{(2) シナリオの設定}

各シナリオは, 歩道幅・歩行者密度・対象となる車 両の種類・対象となる車両の希望速度 - 対象となる車 両の挙動の組み合わせで構成される. これらのシナリ オは寸べて単路の歩道で実行される.また, 歩行者は双

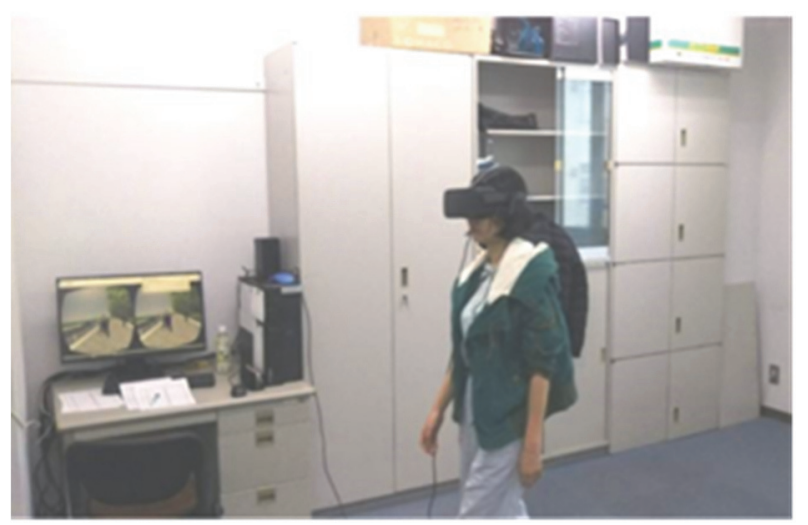

図-15 VR装置と実験の様子

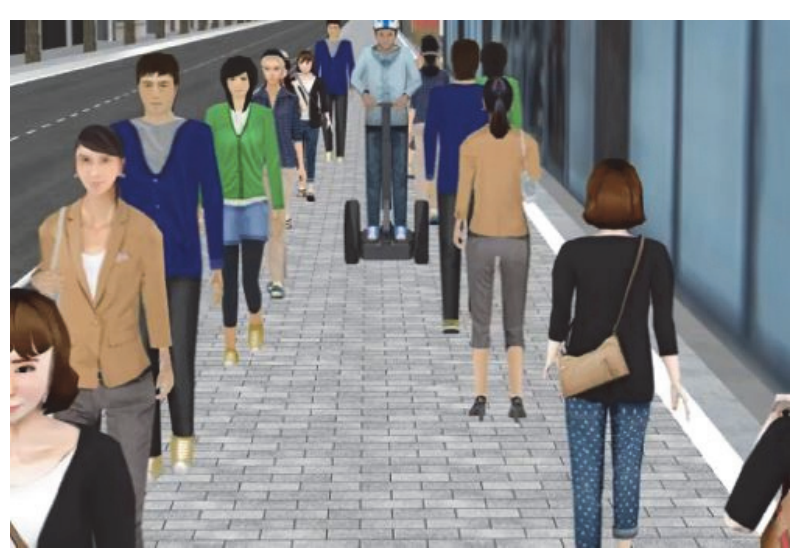

図-16 VR空間の映像例

方向に歩いているが，セグウェイや自転車は全て前方 から向かってきて被験者とすれ違うようにした. 歩道幅 には $2 \mathrm{~m}, 2.5 \mathrm{~m}, 3 \mathrm{~m}, 4 \mathrm{~m}$ の 4 種類. 歩行者密度は低密 $(0.1$ 人 $\left(\mathrm{m}^{2}\right)$ と高密 $\left(0.3\right.$ 人 $\left./ \mathrm{m}^{2}\right)$ の 2 種類を用意した.

\section{(3) 実験の進め方}

習熟歩行ののち，88 回の試行を行った. 各試行では, 周りの歩行者やセグウェイの様子を見ながら約 $4 \mathrm{~m}$ 前方 の地点まで, 被験者は前に向かって歩く.ゴールライン に到達することで1回の試行が完了する. 各試行はシナ リオを 44 種類用意し，それぞれのシナリオは 2 回行わ れるように設計した。

なおこの VR 環境において，前方から来る PMVへの 被験者の危険度認知や周辺歩行者に対寸る回避挙動は, 現実環境での実験と概ね差がないことが示されている ${ }^{11) .}$

\section{参考文献}

1) Shaheen, S. A. and Finson, R.: Bridging the last mile: a study of the behavioral, institutional and economic potential of the Segway human transporter, $82^{\text {nd }}$ Annual Meeting of Transportation Research Board, 2003.

2) Ando, R., Li, A., Nishihori, Y. and Kachi, N.: Acceptability of personal mobility vehicles to public in Japan: Results of social trial in Toyota city, Spatial Planning and Sustainable 
Development, Springer, pp. 213-225, 2013.

3) 山中英生, 半田佳孝, 宮城祐貴 : ニアミス指標によ る自転車歩行者混合交通の評価法とサービスレベル の提案, 土木学会論文集, No. 730/IV-59, pp. 27-37, 2003.

4) 谷口綾子：自動運転システムの社会的受容一賛否意 識とリスク認知, 自動車交通研究, 2018 巻, 2018.

5) 中川智皓, 中野公彦, 古賀誉章, 須田義大, 川原崎 由博, 小坂雄介：パーソナルスペースを用いたパー ソナルモビリティ・ビークルと歩行者の親和性評価 実験, 日本機械学会論文集 $\mathrm{C}$ 編, 76 巻 77 号, pp. 2493-2499, 2010.

6) Dias, C., Iryo-Asano, M., Nishiuchi, H. and Todoroki, T.: Calibrating a social force based model for simulating personal mobility vehicles and pedestrian mixed traffic, Simulation Modelling Practice and Theory, Vol. 87, pp. 395-411, 2018.

7) 中川智皓, 今村和樹, 新谷篤彦, 伊藤智博 : パーソ ナルモビリティ・ビークルの大きさと歩行者の親和 性に関する実験的研究, 日本機械学会論文集 C 編, 78 巻 794 号, pp. 3332-3342, 2012.
8) 中川智皓, 中野公彦, 須田義大, 川原崎由博, 小坂 雄介 : 歩行空間におけるパーソナルモビリティ・ビ 一クルの安全性と安心感, 自動車技術会論文集, 41 巻 4 号, pp. 941-946, 2010.

9) Hasegawa, Y., Dias, C., Iryo-Asano, M. and Nishiuchi, H.: Modeling pedestrians' subjective danger perception toward personal mobility vehicles, Transportation Research Part F, Vol. 56, pp. 256-267, 2018.

10) Slovic, P.: The Perception of Risk, Earthscan, pp. 137-153, 2000.

11) Iryo-Asano, M., Hasegawa, Y. and Dias, C.: Applicability of virtual reality systems for evaluating pedestrians' perception and behavior, Transportation Research Procedia, Vol. 34, pp. 67-74, 2018.

12) http://aoki2.si.gunma-u.ac.jp/R/factanal2.html

13）長谷川悠, 井料美帆：ヴァーチャルリアリティ環境 での歩行者実験に適した歩行者モデルの開発，第 15 回 ITS シンポジウム 2017, 2017.

(Received February 22, 2019)

(Accepted August 26, 2019)

\section{IMPACT OF PERSONAL MOBILITY VEHICLE TYPES ON PERCEPTION OF RISKS BY PEDESTRIANS}

\section{Takayuki HISHIKAWA, Miho IRYO and Yu HASEGAWA}

Personal mobility vehicles (PMV) are compact, superior to environmental performance and paid their attention as a local transportation mode. For deployment of PMV social acceptance on PMV whether pedestrians can subjectively accept the pedestrian-PMV mixed traffic has to be examined. This research aims at investigating characteristics of the risk recognitions of pedestrians under mixed traffic considering type of PMV and pedestrian attributes. Questionnaire surveys were conducted to ask about the risk toward various vehicle types. The result of factor analysis showed two points; 1) sitting vehicle type is perceived as less risky than standing vehicle type by pedestrian, 2) risk perceptions are significantly different by pedestrian attributes (i.e. knowledge of PMV, sex, walking behavior, walking habit and age). 